\title{
Pliocene to Pleistocene Stratigraphy of Rembang Zone, North East Java Basin, Indonesia
}

\author{
Khoiril Anwar Maryunani ${ }^{\mathrm{a},{ }^{*},}$ Rubiyanto Kapid ${ }^{\mathrm{a}}$, Djuhaeni ${ }^{\mathrm{a}}$, Wahyu Dwijo Santoso ${ }^{\mathrm{a}}$, \\ Dasapta Erwin Irawan ${ }^{a}$ \\ ${ }^{a}$ Faculty of Earth Sciences and Technology, Institut Teknologi Bandung, Jalan Ganesa No. 10, Bandung, 40132, Indonesia \\ Corresponding author: *anwar@gl.itb.ac.id
}

\begin{abstract}
We studied benthic faunas and planktonic foraminiferas in seven stratigraphic sections in Rembang Zone to understand the paleoecology of the area. Rembang Zone is an interesting object for further examination especially during Plio-Pleistocene. That time fragment holds a very important information of ecological changes in Java Island. We observed the following sections: upper-part of Ledok fm, calcareous shales/marls of Mundu fm, glouconitic Globigerinid sands of Selorejo fm, and blue-green shales of Tambakromo Member of Lidah fm. We identified N21 sequence in the Late Pliocene, with a sequence boundary (SB-21) which is superimposed with irregular contact between marl of Mundu fm and Globigerinid sands of Selorejo fm. This irregular contact is interpreted as the base of an incised valley, which was generated by a falling sea-level event in Late Pliocene. We spot changes in biostratigraphy, paleobathymetry, and paleoclimate. There are three Pliocene biostragraphies in this section: Globorotalia margaritae zone (N19); Globorotalia miocenica zone (N20 - N21) and Globorotalia tosaensis tosaensis zone (the top of N21). Using cluster analysis with Past computer software, we describe the correlation between variation of foraminifera and environmental change and the bathymetry zone. We find paleoclimate changes by the presence of sub-tropical transitional faunas (Globorotalia tosaensis tosaensis) and the increasing of tropical fauna (Globorotalia truncatulinoides) in Plio-Pleistocene sediments.
\end{abstract}

Keywords—Rembang zone; North East Java basin; biostratigraphy; foraminifera; paleobathymetry; paleoclimate.

Manuscript received 25 Nov. 2019; revised 5 Oct. 2020; accepted 4 Feb. 2021. Date of publication 30 Jun. 2021. IJASEIT is licensed under a Creative Commons Attribution-Share Alike 4.0 International License.

\section{INTRODUCTION}

Paleoecology has not been the main conversation in the paleontology community [1], [2], especially in Indonesia [3]. Lacking long term fossil and drilling data was the primary barrier. Therefore, research papers discussing this topic are not easy to find, especially those published in national journals. The objective of this paper is to discuss the quantitative analyses of benthic and planktonic foraminiferas from seven stratigraphic units: Gunung Panti (GP), Kali Lempungan (KL), Djati Klampok (DK), Kali Klangkrang (KK), Nglebur (GL), Ngampon (NG), Kali Ngliron (NL). All units are located in Rembang Zone of the Northeast Java Basin, Central Java (Figure 1).

The geology of Java is still interesting to unravel (Figure 2 ). The study site exposes an intensive structural feature. The NE-trending horst and grabens were developed in the offshore region of the present-day NE Java Basin (Figure 1). A shift in the subduction front in the Eocene - Oligocene period had occurred in the NE Java Basin as we identified the uplifted and eroded layers. Subsequent tectonic quiescence occurred in the Miocene, following the rejuvenated and contraction tectonic in the Late Miocene because of the active subduction to the south of Java up to the present day. The pre-existing grabens within the E-W trend zone of Rembang-MaduraKangean (RMK) Fault Zone were reactivated as a result [4]. The pre-existing graben faults were reactivated producing many inversion structures concentrated, mostly within the EW of Rembang-Madura-Kangean (RMK) Fault Zone. Previous studies in the N-E Java Basin has been carried out by various oil companies and research institutions [4]-[10], [10]-[14].

\section{MATERIAL AND METHOD}

We classified rock types based on their texture and structure. Then we extracted microfossil samples from rock samples [15]. A Nikon 3.5x-180x was used for dissecting zoom stereo microscope to observe the extracted microfossils. We used cluster analysis on foraminifera species based on [15], [16]. 


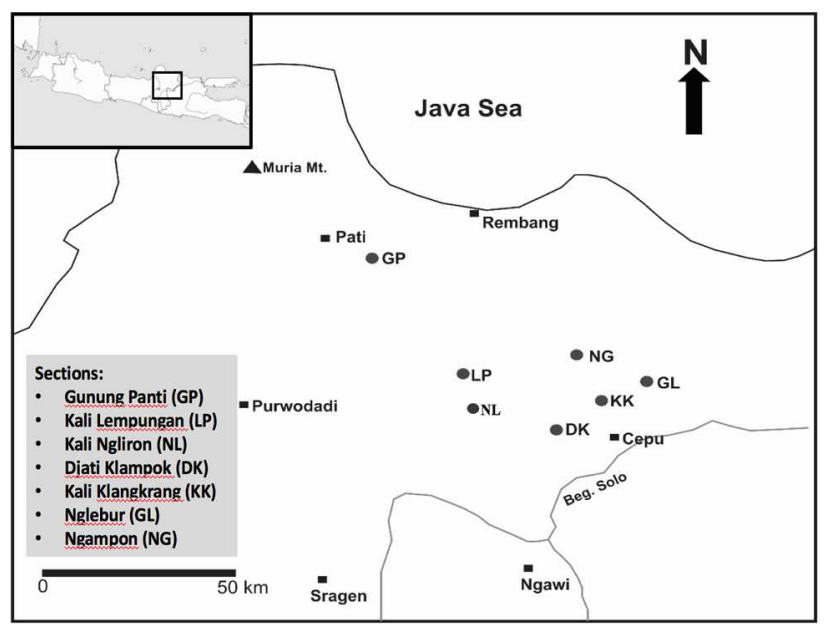

Fig. 1 Location Map of 7 Stratigraphic Sections in Rembang Zone, NE-Java Basin

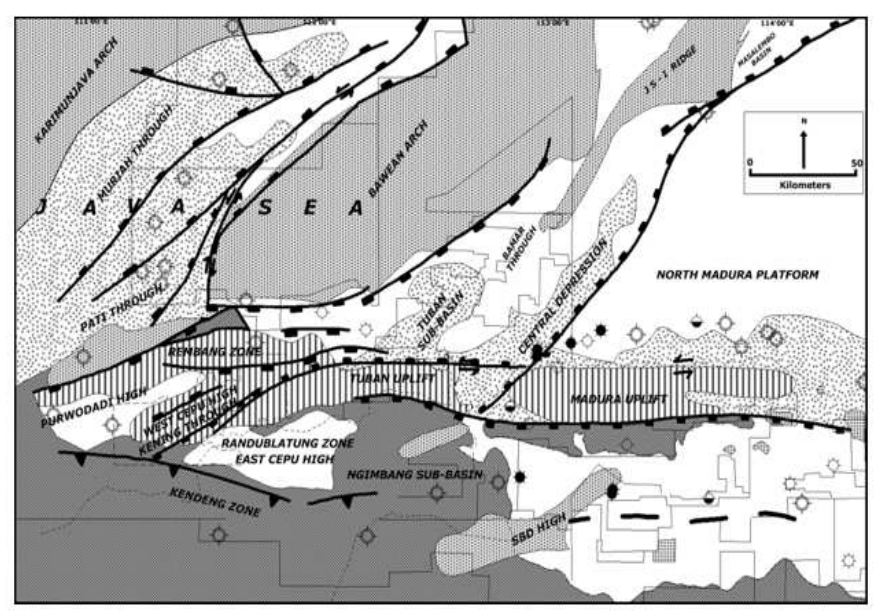

Fig. 2 Location Map of seven Stratigraphic Sections in Rembang Zone, NEJava Basin

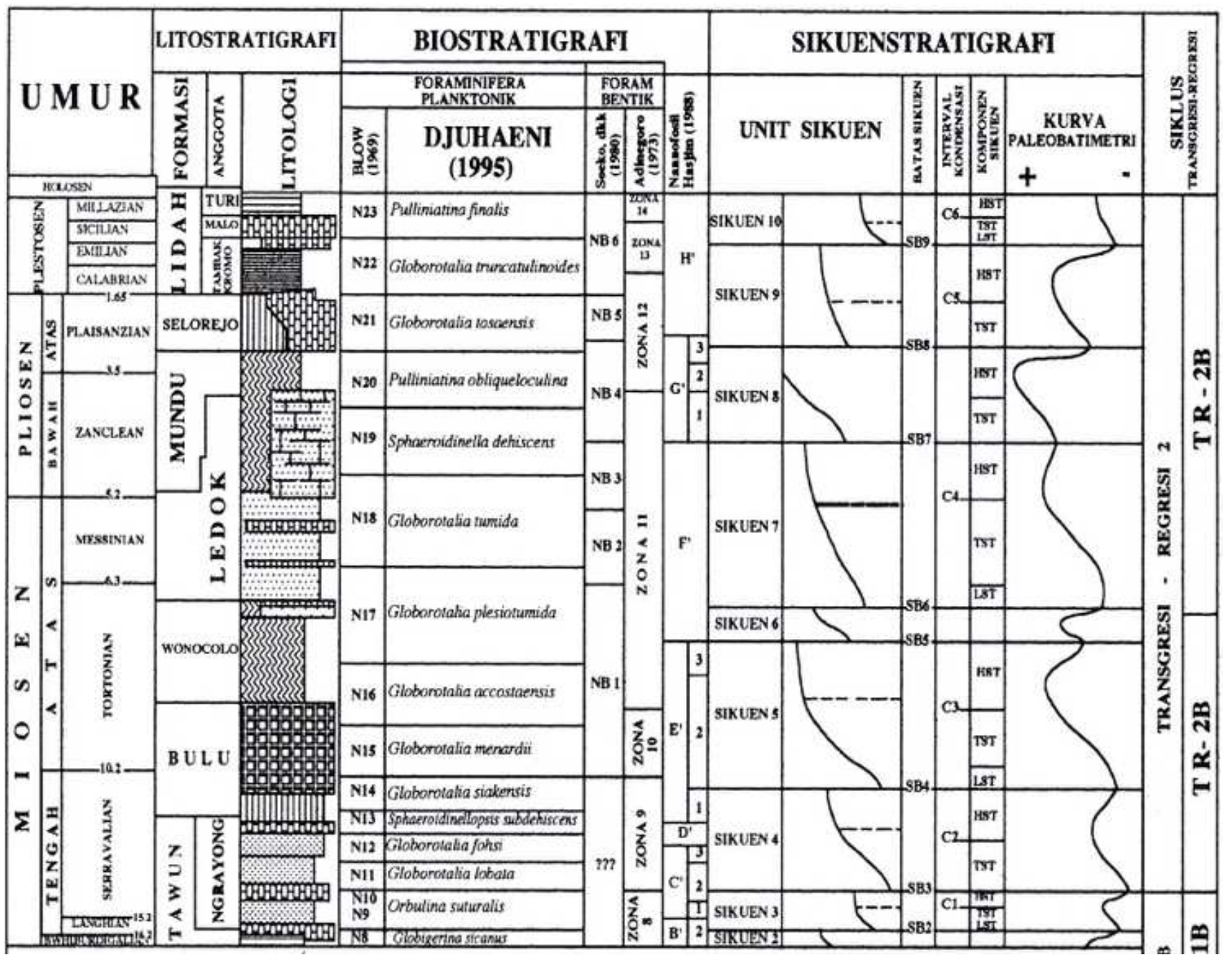

Fig. 3 Stratigraphic column of the Rembang Zone, NE-Java Basin [13] (Translation: umur=age, atas=upper, bawah=lower, formasi=formation, anggota=member, unit sikuen=sequence unit, batas sikuen=sequence boundary, interval kondensasi=condensation interval, komponen sikuen=sequence component, kurva paleobatimetri=paleobathimetry curve, siklus transgresi-regresi=transgression-regression cycle) [11][17][24][25]

These analyses were carried out to determine the biostratigraphy, paleoenvironment, and paleoclimate conditions during Pliocene's deposition-Pleistocene sedimentary rocks in the area. The analyses were carried out to determine the biostratigraphy, paleoenvironment, and paleoclimate settings during Pliocene's deposition -
Pleistocene sedimentary rocks. All figures and tables are uploaded independently as supplementary materials (ppt format) [23]. Figure 4 to Figure 8 are only available in the supplementary file, therefore we would suggest readers to download the slides before reading this paper. 


\section{RESULTS AND DISCUSSIONS}

\section{A. The Regional Geology of Java Basin}

We summarize the geological history of the N-E Java basin as follows:

- Eocene-Oligocene of Ngimbang and Kujung Formations which equal to the syn-rift deposits,

- Miocene-Pliocene of alternating bioclastic limestones, quartz sandstones, and shales of Tawun Formation, quartz-sands of Ngrayong Formation, calcareous shales of Wonocolo Formation (Figure 3), and

- Plio-Pleistocene of shallow marine of Ledok Formation, deep-water sediments of calcareous shales/marl of Mundu Formation, Globigerinid Sands of Selorejo Formation, blue claystones of Tambakromo Member of Lidah Formation, qoquina limestones of Malo Member and green shales of Turi Member of Lidah Formation.

\section{B. Lithostratigraphy}

This paper discusses the Pliocene to Pleistocene deposits, consists of upper-part of Ledok Formation, calcareous shales/marls (Figure 4A) of Mundu Formation, glouconitic Globigerinid Sands (Figure 4B) of Selorejo Formation, and blue-green shales (Figure 4C) of Tambakromo Member of Lidah Formation.

Previously the Pliocene-Pleistocene period is represented by alternating quartz sandstone, bioclastic/calcarenite limestone, and calcareous shale of Ledok Formation (Section KK, Figure 5). Then it passes vertically into platform limestones of Paciran Formation, which interfingering with the monotonous calcareous shales or marls of Mundu Formation in the deep marine sediments. The bioclastic/calcarenites limestones of Ledok Formation's upper part often correlate with the lower part of chalky limestones of Paciran Formation or Karen Limestones.

The RMK Zone appeared to be highly controlled by the topography. Limestones of the Karen/Paciran Formation and the Globigirenid-sands of the Selorejo Formation are commonly carbonate platforms on the platform's high part. In the basinal area, we found pelagic carbonate deep-water deposits more prominent.

Onshore, along the Ngliron River section, the Pleistocene age is represented by the Malo and Turi Member of the Lidah Formation. The Lidah Formation is represented by the blue claystone of Tambakromo Member which was unconformably deposited above the Globigerinid Sands of Selorejo Formation in sections GP, DK, LP. We found another uncomformability along the NG section, when Tambakromo member overlain the marl of Mundu Formation (Figure 6). This vertical succession of Lidah Formation shows the shallowing upward, which marked the end of the regression period in the NE-Java Basin.

Kali Ngliron/NL Section (Figure 7) is used as a model to identify the sequence unit (Sequence-N21) of the Late Pliocene age in the Rembang Zone. Sequence boundary (SB), note as SB-N21, superimposed with irregular contact between marls of Mundu Formation and Globigerinid sands of Selorejo Formation. A biostratigraphic unconformity occurred in the SB-N21 between biozone N19 at the base and N21 above. We interpreted SB-N21 as a representation of force regression, by looking at: the sharp changes of upper bathyal zone deposits of marls (upper part of Mundu Formation) at the base and inner-neritic zone (nearshore to offshore) deposits of Globigerinid Sands of Selorejo Formation on top (Figure 6). This SB was also marked by reworked fossils in the lower as well as upper SB surface.

\section{Paleobathymetry}

The drastic decrease of paleobathymetry from bathyal to nearshore of the inner neritic environment suggests a significant uplift and subsequent erosion at the base of The Selorejo Formation, which contains abundant reworked fossils and indicates the unconformity followed by sequence boundary SB-N21 [10]. A similar interpretation shows the drastic decline of abundance and diversity at Mundu and Selorejo Formation's contact in the Gunung Panti section [9].

Sequence-N21 of Late Pliocene classified into Transgressive System Tracts (TST) deposits, and Highstand System Tracts (HST) deposits (Figure 7 and Figure 8). Both system tract, TST, and HST deposits was separated by Peak Abundance and Diversity (PAD-N21). The TST deposits consist of cross-bedded Globigerinid Sands and glouconitic quartz-sandstones of upper-surface deposits, then deepened as indicated by the blue-claystone, which were deposited in the offshore region. The TST deposit was deposited in the incised valley during transgression. All the HST deposits in this study area were composed of the marine environment's blue claystone, which was deposited in the semi-restricted basin and showed deepening and shallowing succession upward to the upper part.

We determined the evolution of the biostratigraphy, paleobathymetry, depositional environment, and paleoecology, paleoclimate accurately, based on quantitative analysis of planktonic and benthonic micro-fossils in the Kali Ngliron/NL-section (Table 1).

\section{Biostratigraphy}

Kali Ngliron section (NL) consists of upper-part marls of Mundu Formation, Globigerinid Sands of Selorejo Formation, blue shales of Tambakromo Member of Lidah Formation, coquina limestones of Malo Member of Lidah Formation, and green claystone of Turi Member of Lidah Formation. Twentysix samples were taken systematically in the Mundu Formation (sample number 26 to 24), Selorejo Formation (sample number 23 to 18), and Tambakromo (sample number 17-8), Malo Member 7-3, and Turi Member (sample number 2-1). We classified the NL section's biozone into Globorotalia margaritae Zone, Globorotalia miocenica Zone, Globorotalia tosaensis tosaensis Zone, based on analysis of planktonic foraminifera [17].

1) Globorotalia margaritae Zone: Globorotalia margaritae zone is represented by sample 26, which was taken in the Mundu Formation. The occurrence of Globorotalia margaritae evoluta and Globorotalia crassaformis crassaformis mark this zone. The absent of Globigerinoides trilobus fistulosus and the domination of dextral Pulleniatina spp related to the Globorotalia margaritae zone - Globorotalia margaritae evoluta subzone that correlates with N19 zone of Early Pliocene. 
2) Globorotalia miocenica Zone: This zone, N20-N21 zone, is represented by the sample number 25 (Mundu Formation) and is indicated by the occurrence of Globigerinoides trilobus fistulosus and Globorotalia tosaensis tenuitheca, and the absent of Globorotalia tosaensis tosaensis. This zone correlates with Middle Pliocene. The presence of Globoquadrina dehiscens s.l. and Globigerina venezuelana is interpreted as a reworked fossil.

3) Globorotalia tosaensis tosaensis Zone: This zone is interpreted by the first appearance of Globorotalia tosaensis tosaensis, the occurrence of Globigerinoides extremus, and Globorotalia truncatulinoides still not yet present at the top of this zone. This zone correlates to the top of the N21 zone, which is equal to Late Pliocene. More reworked fossils are observed from samples 23 to 17, for examples: Globigerinoides trilobus fistulosus and Sphaeroidinellopsis seminulina. These were also observed in samples interval between number 8 to 2 . This Globorotalia tosaensis tosaensis Zone is not clearly defined due to the abundance of reworked fossils.

\section{E. Depositional Environment and Paleoecology}

A change in paleobathymetry from the Mundu to Lidah formation as suggested by the foraminifera's abundance and diversity was due to a change in paleoclimate. Marl units of the Mundu Formation was deposited in the bathyal environment between $400-1000 \mathrm{~m}$ [9], which shows the high diversity but low abundance. The deepest environment was indicated at the top of Mundu Formation that marked by the highest diversity and abundance. The lowest abundance and diversity foraminifera can be observed at the contact between Mundu and Selorejo Formations. This trend was caused by force regression and drop sea level which enforces the major erosion and triggers unstable environment for foraminifera.

We performed a cluster analysis (Figure 9) to interpret the depositional environment. Sample 24 and 26, which was deposited in the deeper part of outer neritic to upper bathyal of the Mundu Formation are clustered into one group. The samples reflect an open marine environment with low oxygen content in the basin substrate, a high diversity of planktonic and benthonic foraminifera: Parafrondicularia, Hoeglundina elegans, Oridorsalis umbonatus, Planulina wuelerstorfi, Pullenia bulloides, Siphonina australis, Sphaeroidina bulloides, and the domination of low oxygen benthonic foraminifera that can reach up to $40 \%$.

The second cluster is performed to sample numbers 23 to 17 (Selorejo Formation), which are dominated by the large crossbedding of glauconitic Globigerinid sandstones, and bioclastic limestones. The benthonic foraminifera association is similar to the first cluster but with a clear difference in abundance. This interval revealed the increasing of middle outer neritic (such as Lenticulina, Heterolepa, Bulimina, and Uvigerina) and bathyal foraminifera. Reworked fossils are commonly observed in this cluster, and they indicate that the bathyal foraminifera from this interval came from the older formation (Mundu Formation). This second cluster was deposited in the deeper part of the middle neritic to the shallow part of the outer neritic. The bottom part of this cluster was sedimented in the incised valley during transgression.
The third cluster is represented by sample 16 to sample 10 (lower part of Tambakromo Member of Lidah Formation). This interval is dominated by drastically decreasing diversity and abundance of planktonic and benthonic foraminifera. The low oxygen of foraminiferas species such as Bulimina, Bolivina, and Uvigerina predominates this interval. The Buliminida fauna (Bulimina, Bolivina, and Uvigerina) survive and reach the peak population in the low oxygen environment, lower than $0.1 \mathrm{ml} / \mathrm{L}$ [20] to $0.31 \mathrm{ml} / 1$ [16]. This condition reflects those sediments were deposited from the open to semi-restricted oceanic circulation in the deeper-part of the middle neritic to the shallow-part of outer neritic and followed by the decreasing of oxygen content caused by closing marine condition. This condition laid supportive conditions for the low oxygen foraminifera taxa as well as decreased diversity and abundance of foraminifera. Moreover, the restricted marine is supported by the low energy environment from this interval, which is reflected by a thick blue claystone interval.

Sample 8 and 9 represent the fourth cluster that was taken from the upper part of the Tambakromo Member of the Lidah Formation. The lithology changes from claystone to sandy claystone containing abundant and diverse foraminiferas. Some of the planktonic and benthonic foraminiferas in this interval such as Globigerina venezuelana, Globigerina nephentes, Sphaerodinellopsis seminulina, Globoquadrina dehiscens, Globorotalia margaritae margaritae, and Globorotalia merotumida are reworked fossils. The occurrence of large foraminifera, rotaliid foraminifera (Pseudorotalia, Asterorotalia, Ammonia, Ammonia beccarii), and elphidiid is interpreted as ecology changes in this environment, from semi-restricted to open marine condition of middle neritic. A similar situation in the South China Sea's recent sediments is deposited at the $50 \mathrm{~m}$ depth or lower euphotic zone [18]. The abundance of Pseudorotalia and Asterorotalia is interpreted to represent a low energy open marine environment.

The Malo Member of Lidah Formation (from sample 2 to sample 7), consist of coquina limestones, sandy claystone, and interbedded glauconitic sandstones. The erosional surface is observed at the contact between shales of Tambakromo Member and coquina limestones of Malo Member. In the fifth cluster, sample 7 to 5 , the abundance of rotaliid and large foraminifera are drastically decreased. Moreover, the middle neritic foraminiferas are absent. The planktonic foraminiferas show reworked fossils and mixing of shallow-deep water benthonic foraminifera. Gastropods and shell fragments are dominant in this interval. This condition reflects the shallowing bathymetry with high energy in the inner neritic zone.

The sixth cluster, represented by sample 4, shows an increase of rotaliid and elphidiid (Pseudorotalia, Elphidium, Asterorotalia, and Ammonia). The existence of middle neritic foraminiferas (Heterolepa praecincta, Lenticulina) indicates the deepening environment in the inner neritic. Samples 2 and 3 were taken from the upper part of Malo Member in the glauconitic sandstone interval and grouped into the seventh cluster. The two samples reflect the deepening-up, which marked by high diversity and abundance of planktonic foraminifera and the domination of Lenticulina, Heterolepa praecincta, Bulimina, Bolivina, and Uvigerina. 


\section{F. Paleoclimate}

On the Late Pliocene, generally, the climate changes from warm to cool and followed by shallowing upward. This event occurred after the first appearance of Globorotalia tosaensis tosaensis and before the occurrence of Globorotalia truncatulinoides, within the interval of $3 \mathrm{Ma}$ [19] to $1.95 \mathrm{Ma}$ [20]. The global cooling phase on the Pliocene has occurred from 3.35 to $2.3 \mathrm{Ma}$ [21], [22].

In the Kali Ngliron/NL section (Figure 10), the cooling phase is observed from the upper Mundu Formation to the Tambakromo Member of the Lidah Formation (samples 25 to 8 ). Samples 8 to 25 show temperature fluctuation and are dominated by sub-tropic-transition faunas. This fact indicates the cooling environment occurred during this interval. Warmer temperature occurred when sample 9 (upperpart shales of the Tambakromo Formation) was deposited, which is marked by the increase of tropical fauna at the upper shales of Tambakromo Member of Lidah Formation.

\section{CONCLUSION}

Reworked fossils can be used to identify the lower and upper parts of sequence boundary N21 (SBN21). We identified the MFS of Sequence N21 using the Pick Abundance and Diversity (PAD) of planktonic and benthonic forminifera. We are also able to identify it by observing benthonic fossil association to indicate maximum paleobathymetry. The regression occurred in the $\mathrm{N} 21$ biozone, characterized by abrupt changes of paleobathymetry from the upper bathyal zone to near-shore environment. This regression produced an incised valley, which then had been filled by high energy cross bedded glauconitic Globigerinid Sands of Selorejo Formation during the transgression period. During the Pliocene, N-E Java Basin, the basin's ecology changed from open marine to semi-confined, which correlated to the deposition of middle-part blue shales Tambakromo Member of Lidah Formation.

\section{SUPPLEMENTARY MATERIALS}

For easy reading, we deposited all figures and tables as supplementary materials as PNG figures and Powerpoint slide format [23].

\section{ACKNOWLEDGMENT}

We are grateful to P3MI-ITB for the partial funding and Laboratory Micropaleontology Institut Teknologi Bandung for the technical support. We are also grateful to Rudi Lesmana and Rifky Ghifari for their contribution in preparing samples and figures.

\section{REFERENCES}

[1] J. R. Beerbower, 'New Perspectives in Paleontology', J. Geol. Educ., vol. 11, no. 3, pp. 95-97, 1963.

[2] K. C. Maguire, D. Nieto-Lugilde, M. C. Fitzpatrick, J. W. Williams, and J. L. Blois, 'Modeling species and community responses to past, present, and future episodes of climatic and ecological change', Annu. Rev. Ecol. Evol. Syst., vol. 46, pp. 343-368, 2015.
[3] D. E. Irawan and R. Kapid, 'A review on paleoenvironment suitability for hominid fossils and other early vertebrate faunas: a case from Pucangan and Kabuh Formations, Central and East Java, Indonesia', Sci. Res., Jun. 2017, doi: 10.14293/s2199-1006.1.sor-life.ah9puy.v1.

[4] C. S. Kenyon, 'Distribution and Morphology of Early Miocene Reefs, East Java Sea', Indones. Pet. Assoc., pp. 215-238, 1977.

[5] H. Pringgoprawiro, 'Biostratigrafi dan Paleogeografi Cekungan Jawa Timur Utara: Suatu Pendekatan Baru', PhD Thesis, Institut Teknologi Bandung, Bandung, 1983.

[6] P. Baumann, 'Depositional Cycle on Magmatic and Back-Arc: An Example from Western Indonesia', Rev. L'Institute Francais Pet., vol. 37, no. 1, pp. 3-17, 1982 .

[7] A. Muin, 'Constribution a la Geologie du Basin Nord Oriental de l'Il de Java, Indonesie: Sedimentologie d'un Bassin d'Arrier Arc', PhD Thesis, Universite Scientifique et Medicale de Grenoble, France, 1985.

[8] L. Samuel and M. Johannes, 'Perlapisan silang-siur sebagai penunjuk arah arus purba di Daerah Utara Cepu, Jawa Tengah', in Ann. Conv. XVth IAGI, Yogyakarta, 1986.

[9] R. Kapid, 'Le mio-pliocene marin du nord-est de java, indonesie. Biostratigraphie qualitative et quantitative des foraminiferes et du nannoplancton', PhD Thesis, Reims, France, 1991.

[10] D. Djuhaeni, 'Stratigraphie Sequentielle Des Series Sedimentaires Marines du Neogene et du Pleistocene dans Region de Cepu, Bassin Nord-Est de Java', Disertasi Doktor, Universite Claude-Bernard du Lyon-I, France, 1994.

[11] D. Djuhaeni, 'Efek Tektonik dan Eustasy Terhadap Perkembangan Sikuen: Suatu contoh pada Endapan Miosen Atas Plestosen di Daerah Cepu, Cekungan Jawa Timur Utara', in Prosiding PIT-IAGI, Bandung, 1996.

[12] D. Djuhaeni, 'Signifikasi Aplikasi Konsep Sikuenstratigrafi pada Endapan Berumur Neogen dan Plestosen di Daerah Cepu, Cekungan Jawa Timur Utara', J. Teknol. Miner. -ITB, 1996.

[13] D. Djuhaeni, 'Hubungan antara Fluktuasi Paras Muka-laut Relatif dan Biostratigrafi pada Endapan Neogen dan Plestosen di Daerah Cepu, Cekungan Jawa Timur Utara', J. Teknol. Miner. -ITB, 1996.

[14] D. Djuhaeni and S. Martodjojo, 'Studi Batupasir Selorejo Daerah Cepu, Jawa Tengah', in Proc. XIXth. Ann. Conv. IAGI, Bandung, 1990 pp. $162-179$

[15] D. S. Tolderlund and A. W. Bé, 'Seasonal distribution of planktonic foraminifera in the western North Atlantic', Micropaleontology, pp. 297-329, 1971.

[16] J. R. Haynes, Foraminifera. Springer, 1981.

[17] W. H. Blow, 'Late Middle Eocene to Recent planktonic foraminiferal biostratigraphy', in Proceedings of the first international conference on planktonic microfossils, 1969, vol. 1, pp. 199-422.

[18] H. G. Billman and M. Scrutton, 'Stratigraphic correlation in Indonesia', 1976.

[19] J. D. Hays, T. Saito, N. D. Opdyke, and L. H. Burckle, 'PliocenePleistocene Sediments of the Equatorial Pacific: Their Paleomagnetic, Biostratigraphic, and Climatic Record', GSA Bull., vol. 80, no. 8, pp. 1481-1514, Aug. 1969, doi: 10.1130/0016-7606(1969)80[1481: PSOTEP]2.0.CO;2.

[20] T. Saito, P. R. Thompson, and D. Breger, Systematic index of Recent and Pleistocene planktonic foraminifera. University of Tokyo Press, 1981.

[21] J. Van Gorsel and S. Troelstra, 'Late Neogene planktonic foraminiferal biostratigraphy and climatostratigraphy of the Solo River section (Java, Indonesia)', Mar. Micropaleontol., vol. 6, no. 2, pp. 183-209, 1981.

[22] R. Stainforth, J. L. Lamb, H. Luterbacher, J. H. Beard, and R. M. Jeffords, 'Cenozoic planktonic foraminiferal zonation and characteristics of index forms', 1975.

[23] K. A. Maryunani, R. Kapid, D. Djuhaeni, W. D. Santoso, and D. E. Irawan, 'Supplementary material - Pliocene to Pleistocene Stratigraphy of Rembang Zone, North East Java Basin, Indonesia', Zenodo, Nov. 2019, doi: 10.5281/zenodo.3525453.

[24] Adinegoro, 'Stratigraphic Studies by the Indonesian Petroleum Institute', Lemigas, United Nation Escope, CCOP Technical Bulletin, 1973.

[25] Hasjim, N., 'Le Neogene Marin Du Nord Est De Java, Indonesie. Etude Biostratigraphique (Foraminiferes et Nannoplancton) ' GEOMEDIA Fons-Troubado Chemin du Four 13100 Aix en Provence, France, 129 pp, 6 pl, 1988. 